\title{
Bamboo resources in Togo
}

\author{
A. D. KOKUTSE*, K. ADJONOU, A. K. GUELLY and K. KOKOU \\ Laboratoire de Botanique et Ecologie Végétale, Faculté des Sciences, Université de Lomé, Togo. \\ *Corresponding author; E-mail: mimidam@hotmail.com
}

\begin{abstract}
The reduction of the forest resources requires the use of some under-utilized timber and Non Timber Forest Products such as the bamboos. This study analyses the diversity, ecological and morphological characteristics and the uses of 257 bamboos clumps dispersed in different zones in Togo. The results show that most of the clumps are natural groves, occupying $76.6 \%$ of the total bamboo area in Togo, and the proportion of the private plantations is $23.4 \%$. The bamboo clumps are generally of small size. Five local or naturalized species have been encountered: Bambusa arundinacea, Bambusa multiplex, Bambusa vulgaris, Bambusa vulgaris var. striata and Oxytenanthera abyssinica. Twenty other species introduced recently are in experimentation in the Opportunities Industrialization Centers (OIC-Togo). The most two frequent bamboos are Bambusa vulgaris (85.21\% of the clumps) and Oxytenanthera abyssinica (11.28\%). Both bamboo species have a contrasted ecology; the first is abundant in the guinean zone of the country and the second in the sudanese zone. The usual practices assessment of the bamboo species show that in Togo, the production, exploitation and processing are again at the craft level. The management of the forest resources in Togo requires more exploitation of the bamboos species, as an alternative to limit the human pressure on the traditional plant species (Teak, Iroko, Mahogen, Afzelia, etc.).
\end{abstract}

(C) 2014 International Formulae Group. All rights reserved.

Keywords: Non Timber Forest Products, traditional exploitation, management, technology transfer.

\section{INTRODUCTION}

The tropical forests continue to degrade in quantity and quality due to the demand for suitable lands for farming and forest products (Food and Agriculture Organisation of the United Nations, 2001). This situation leads more and more to a sensible reduction of forest resources, including the timbers. A better management and an optimal use of the forest resources still available, is imperative, particularly in the developing countries. In these countries, the use of some timber species, until then under exploited and Non Timber Forest Products (NTFPs) such as the bamboos, constitute an alternative to reduce the current pressure on the forest resources (Food and Agriculture Organisation of the United Nations, 2005; Chen, 2003).

The use of the bamboo in substitution to the usual timbers is frequent in Asia (Muller and Rebelo, 2010; Scurlock et al., 2000). It is for this reason that the International Tropical Timber Organisation (ITTO), the International Centre of Research and Development (ICRD) and the 
International Network of Bamboo And Rattan (INBAR) have financially supported many researches and development projects on the bamboo in Asia and Latin America (Lobovikov et al., 2007). Consequently, considerable information has been accumulated on various aspects of uses of bamboos in these countries. This facilitates the bamboo processing, from the simple use of culms to craft objects, ply-wood, paper and fibre producing and in terms of carbon sequestration (Scurlock et al., 2000; Song et al., 2011; Abdul Khalil et al., 2012).

In Africa, certain countries (Zambia, Kenya, Tanzania, Uganda and Ethiopia) have recently undertaken vast research works on the sustainable use of their bamboo resources (Embaye et al., 2003; Muller and Rebelo, 2010). In Togo, there are no reliable data on the bamboos and no serious research has been carried out. The only information available comes from the flora of Togo (Brunel et al., 1984) which reports the presence of the Bambusa vulgaris in the South of Togo and the Oxytenanthera abyssinica in the North, central and south-west parts of the country. The International Network of Bamboo and Rattan in Togo, has also helped to acquire some additional knowledge on the bamboos in Togo (INBAR-Togo, 2002). Recently, Kokou et al. (2006) carried out a survey on the socioeconomy and valorisation of bamboos in Togo, leading to know that the uses are very many and varied: construction, scaffolding and diverse furniture supplies. In addition, Kokutse et al. (2013) showed that the mechanical, physical and anatomical performances of four bamboo species in Togo allowed to use these materials in building industry. Considering the availability of the resource and its place in the local populations needs meeting, an elaborating study on the taxonomy and ecological diversities, and the uses of wild or naturalised bamboos in Togo, would allow to constitute necessary databases for a sustained production, crafty and industrial processing and for a sustainable management. To achieve this goal, this study proposes to assess the bamboos diversity and distribution in Togo to know the intra and inter specific variability enabling to distinguish them on the morphological basis and finally to know the uses of the bamboos. This stage is very indispensable to undertake more elaborating studies on the bamboos in Togo in order to promote their exploitation and sustainable management.

\section{MATERIALS AND METHODS Study area}

The study was conducted in the five ecological zones of Togo (Figure 1). These zones are both different in climate, soil (Lamouroux, 1957) and vegetation type (Figure 1, Table 1) and are classified I - V depending on the flora present (Ern, 1979; Kokou, 1998). The Zone I represents the plains in the northern part of Togo. The typical vegetation is essentially Sudanese savannah (Ern, 1979). The dry season lasts from November to May and the rainy season from June to October. The total rainfall is between 800 and $1000 \mathrm{~mm}$. The temperatures vary between 17 and $39{ }^{\circ} \mathrm{C}$ during the dry season and between 22 and $34{ }^{\circ} \mathrm{C}$ during the rainy season. The Zone II corresponds to the northern part of Atakora Mountains in Togo and is a dry forest zone composed of mosaic guinean savannahs and with climate characteristics of sudanese hills. The dry season is from October to March, and the rainy season from April to October. The yearly rainfall is between 1200 and $1300 \mathrm{~mm}$. The minimal average temperature ranges from 19 to $20{ }^{\circ} \mathrm{C}$ in January, the maximum reaches $30{ }^{\circ} \mathrm{C}$ in April. The Zone III corresponds to the centre plains of Togo dominated by several inselbergs (200 to $400 \mathrm{~m}$ in height) and consists of guinean woody savannahs (Aubréville, 1937). The total rainfall varies 
between 1200 and $1500 \mathrm{~mm}$ per year. The number of rainy days is between 100 and 130 per year. The temperature ranges between 25 and $40{ }^{\circ} \mathrm{C}$. The Zone IV constitutes the southern part of the Atakora Mountains with ideal climatic conditions for semi-deciduous forest growth (Akpagana, 1989). This area is a transitional subequatorial zone (Trochain, 1957) and can be characterized by a long, rainy season lasting from March to October and a short, dry season from November to February (Guelly, 1994). The rainfall amounts range from 1300 to $1600 \mathrm{~mm}$ per year. The Zone $\mathrm{V}$ is the coastal plain of Togo which is considered as a dry littoral zone with a subequatorial climate. Two rainy seasons occur per year, from March to July and from September to November. The total rainfall is between 800 and $1200 \mathrm{~mm}$ per year.

\section{Data collection}

A random inventory, locality per locality and per ecological zone (Ern, 1979) has been conducted to locate the bamboo resources in Togo (Table 1). During this inventory, all the bamboo species present were identified. All the uses observed and signalled out of the interactions with the population were noted.

The sampled bamboo clumps have been characterized ecologically and morphologically. The variables measurement is made at three levels: ecological variables, variables related to clumps and morphological variables of culms. The privileged ecological variables are the altitude, geographical coordinates taken with a GPS, geomorphology, topography, slope, mother rock or cuirass floor covering, nature of the soil, surrounding vegetation and human activity. For the related variables to bamboo clumps, the extension has been estimated qualitatively through its impact on the land: small tract $<150 \mathrm{~m}^{2}(10 \mathrm{~m} \times 15 \mathrm{~m})$, average tract $150-500 \mathrm{~m}^{2}(25 \mathrm{~m} \mathrm{x} 20 \mathrm{~m})$, big tract 500$2000 \mathrm{~m}^{2}(50 \mathrm{~m} \mathrm{x} 40 \mathrm{~m})$ and above. The morphological variables concern the height of the dominant culms, circumference of the mature culms, length of the internodes, number of node, length and width of the sheath, length and width of the limb and length and width of the ligula. Many authors showed that all these morphological, anatomical and physical characteristics have implications on the uses of bamboo species (Rassiah et al., 2014; Banik, 1993; 1997; Liese, 1998). The lengths and the widths are measured with a tape or a graduated ruler. Five mature culms per clumps are chosen randomly for the measurement of these parameters. The circumference of the culm is taken at $0.25 \mathrm{~m}$ from the ground. The thicknesses of culms are mostly measured on the culms already cut by the local populations with a calliper square.

\section{Data processing}

A list of the bamboo species and the localities where they grow is drawn up. Their ecological affinity has been displayed by means of the projection of the geographical coordinates of clumps collected on the geomorphological and ecological subdivision map of Togo, thanks to MapInfo software. An analysis of variance and post-hoc Fisher least significant difference were used to determine differences in the morphological characteristics (the height of the culms, length of the limb, length of the internodes, thickness and circumference of the culms) in order to display the differences between the various species of bamboo in Togo and depending on ecological zones. 


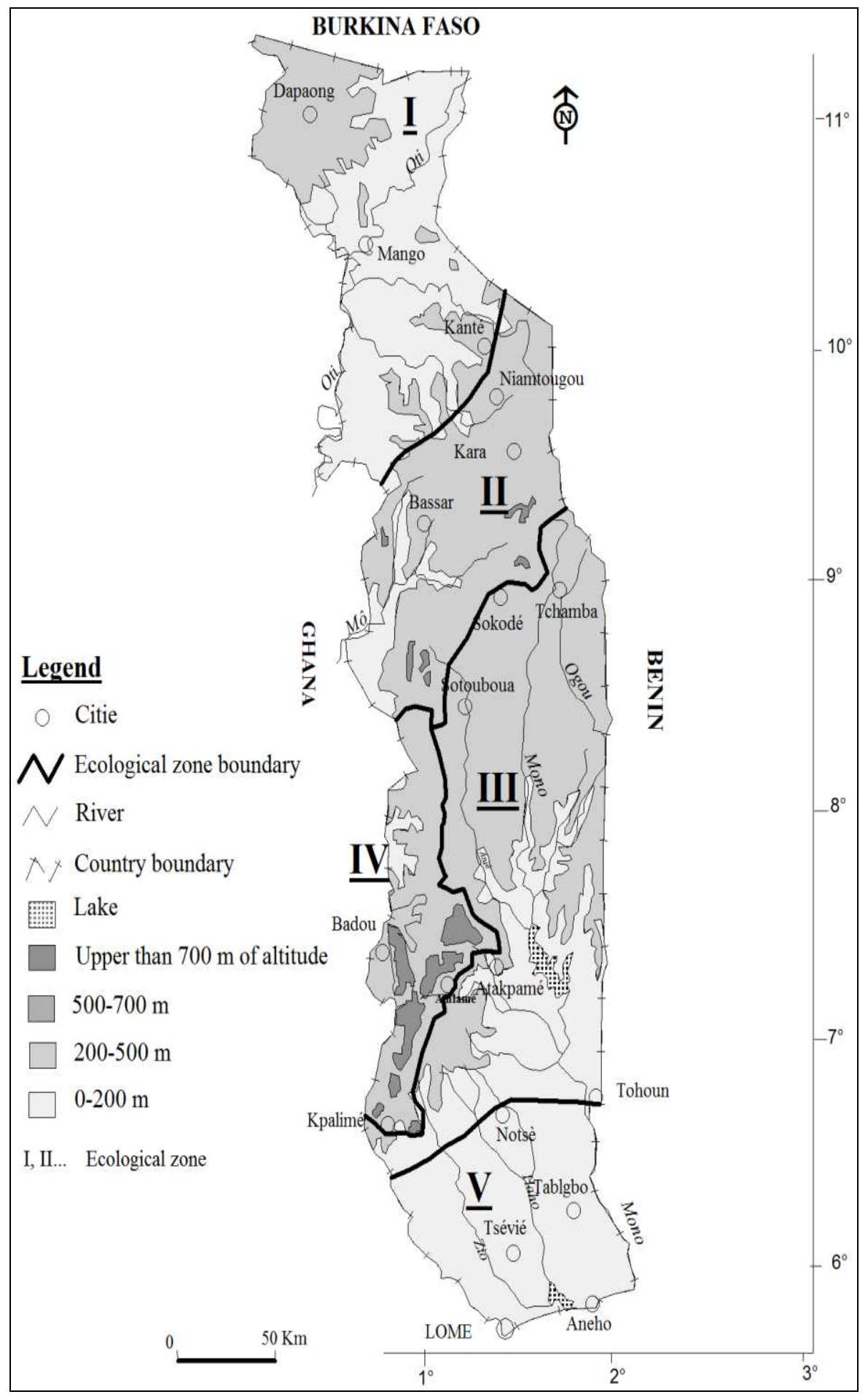

Figure 1: Ecological zone in Togo. 


\section{RESULTS}

Specific and ecological diversities of bamboos

The survey covered 257 sites throughout Togo and has allowed to collect five wild or planted bamboo species. These included: Bambusa arundinacea, Bambusa multiplex, Bambusa vulgaris, Bambusa vulgaris var. striata and Oxytenanthera abyssinica. The most frequent encountered ones are Bambusa vulgaris $(85.21 \%$ of the clumps) and Oxytenanthera abyssinica (11.28\%). The other species of bamboos (Bambusa arundinacea, Bambusa multiplex, Bambusa vulgaris var. striata) represent only $3.51 \%$ of the clumps. Besides, 20 other species, recently introduced, are under experimentation at the Opportunities Industrialization Centers-Togo (OIC-Togo), near Notsé (Table 2).

In terms of ecological affinities, the distribution area of $O$. abyssinica is quite clearly distinct from that of the other bamboos (Figure 2). It occupies the ecological zones I and II and can stretch up to zone IV, generally on the top and half slope of mountains at altitudes that can reach $600 \mathrm{~m}$. It develops on stony lands or gravelled and sometimes amidst the blocks of the mother rock. In the North (zone I), the species have been found on the cuirass soil indicating the high adaptation to the extreme ecological conditions. The characteristic vegetations of $O$. abyssinica biotopes are wood savannah and dry forests. Some clumps of the $O$. abyssinica are found in semi deciduous forest on the Akposso plateau and around Badou township (Zone IV). The other bamboos grow preferentially in the ecological zone III, IV, and V. The species of Bambusa genera are more abundant in plain, but also on tablelands with altitudes that can reach $500 \mathrm{~m}$. B. vulgaris is generally recorded on the embankment of streams, in the hollows and on flat grounds, substratum with no heavy weight. It has more frequently been found also in the peripheral zones of semi deciduous forest (e.g. in forest galleries, dry forests, savannah and human disturbed vegetations).
Concerning area occupied by the different species of bamboo, B. vulgaris occupies $82.9 \%$ of the clumps while $O$. abyssinica occupies $12 \%$ (Table 3). The other bamboos occupy only $7 \%$ of the areas. Concerning the two main species, there are as many as small bamboo clumps compared to the big ones. The ecological zones containing more clumps are:

- for B. vulgaris, the ecological zones IV and $\mathrm{V}$ account respectively for 35 and $28.1 \%$ of the bamboo areas (Table 4). This is followed by zone III $(10.8 \%)$, then zone II (7.6\%);

- for $O$. abyssinica, the most important clumps are in the ecological zone II with $8.1 \%$, zone I and IV represent the rest of the areas, i.e., $1.9 \%$ each (Table 4).

\section{Morphological characteristics}

$O$. abyssinica botanical characteristics distinguish this species from the other main bamboos ( $B$. vulgaris and $B$. vulgaris var. striata), by the presence of ligula (Table 5). With the B. vulgaris, the sheath has a length which varies between 6.7 and $9.3 \mathrm{~cm}$ and a width ranging between 0.6 and $0.9 \mathrm{~cm}$. The limb has a length which varies between 19.5 and $28.5 \mathrm{~cm}$ and a width ranging between 2.9 and $3.9 \mathrm{~cm}$. B. vulgaris var. B. striata has a sheath whose length is between 8 and $9.2 \mathrm{~cm}$, and a width between 0.7 and $1 \mathrm{~cm}$. The length of the limb is between 4 and $4.1 \mathrm{~cm}$. Put aside the exact difference between the leaves of $O$. abyssinica (presence of ligulae) and that of the other bamboos, it is not easy to recognize the 5 species according to their leaves, therefore by means of herbarium samples.

However, the morphological characteristics of culms help to distinguish them more easily. Considering the height of the culms, O. abyssinica and B. vulgaris are significantly different from each other $\left(\mathrm{F}_{257,2}=\right.$ $14.73 ; \quad \mathrm{P}<0.001)$, even though the characteristics "height" does not allow to distinguish B. vulgaris from B. vulgaris var. striata. On the length of the internodes, the Fisher test allows to differentiate very significantly $B$. vulgaris, $B$. vulgaris var. 
striata and $O$. abyssinica $\left(\mathrm{F}_{117,2}=7.51\right.$; $\mathrm{P}<0.001)$. The circumference of the culms distinguishes clearly $O$. abyssinica from $B$. vulgaris $\left(\mathrm{F}_{100,2}=21.47 ; \mathrm{P}<0.001\right)$; but does not allow to distinguish $B$. vulgaris var. striata from B. vulgaris. The thickness of the culms is also a discriminating characteristic of the diverse bamboo species morphology. It helps to distinguish $O$. abyssinica from the other species $\left(\mathrm{F}_{98,2}=66.18 ; \mathrm{P}<0.001\right)$.

The culms of $B$. vulgaris in the ecological zone IV are the most giant in Togo (Table 6). This characteristic would be linked to the fact that soils are rich there (forest zone of Togo), favouring a better development of culms but also because the resource over there is subject to less pressure. The length of the internodes varies very little from one zone to another, between $27.74 \mathrm{~cm}$ and $1.85 \mathrm{~cm}$. The culms of B. vulgaris are very big in zones IV and II (Table 6), probably for reasons already mentioned above (zone II carries also some fragments of semi deciduous but mostly dry forests). The culms of B. vulgaris in zone IV are as big as those in zone II with culms, reaching respectively 25.07 and $24.60 \mathrm{~cm}$ of circumference. The culms of $B$. vulgaris which are morphologically mediocre are located in zone $\mathrm{V}$ where the average height and the average circumference are lower (Table 6). This relative mediocre performance is due to the fact that the bamboos in that zone are more required for domestic uses. In terms of thickness of the culm, the zone II presents the thickest ones (in average $2.16 \mathrm{~cm}$ ). Despite the fact that the circumference of the culm is important in zone IV, the individuals of Bambusa vulgaris present there are of a relatively low thickness $(1.8 \mathrm{~cm}$ in average).

B. vulgaris var. striata can reach 25 $\mathrm{cm}$ of height and $20.60 \mathrm{~cm}$ in average in zone $\mathrm{V}$. This bamboo remains, for the mean time, a horticultural plant and its exploitation for domestic uses is just at its beginning, notably in zone IV. The average length of the internodes varies very little, respectively $24.00 \mathrm{~cm}, 25.16 \mathrm{~cm}$ and $25.30 \mathrm{~cm}$ for zones II, IV and V. The biggest individuals are found in ecological zone IV where they reach an average circumference of $29.20 \mathrm{~cm}$. The individuals collected in the other zones are of smaller dimensions $(20.91 \mathrm{~cm}$ of circumference for zone $\mathrm{V}$ and $19.5 \mathrm{~cm}$ for zone II). Contrary to B. vulgaris, B. vulgaris var. striata presents the average thickest circumference in zone IV (an average of 2.26 $\mathrm{cm}$ against $1.59 \mathrm{~cm}$ ).

O. abyssinica measures $8.50 \mathrm{~m}$ and $13.20 \mathrm{~m}$ in height, respectively in zone I and II. In the zone IV where the species is also present, the average height measured is $12 \mathrm{~m}$. The internodes are of $28.70 \mathrm{~cm}$ in height for zone I and $30.86 \mathrm{~cm}$ for zone II. The average circumference of the individuals varies from one zone to another, i.e., $11.41 \mathrm{~cm}$ for zone II and $13.08 \mathrm{~cm}$ for zone I. O. abyssinica does not have hole on the culm, at the lower area the culm is completely full, thus making it an easy distinctive characteristic compared to the other bamboos. But when moving toward the central part of the culm, the hole appears.

\section{Practices and uses linked to the exploitation of bamboo}

The Zones II, IV and V appear as the most prolific in bamboo clumps, mostly in the B. vulgaris. The other zones (I and III) are those of average use of bamboo. Most of the clumps visited are from the natural groves (76.6\%) and the proportion of the private plantations is $23.4 \%$. Making a link between the origin of the bamboo clumps and the planting areas, it appears that the zone IV is the supplying zone for $20.4 \%$ of the bamboo planted in Togo (Table 7). This indicator can be explained by the fact that the zone IV is a hosting farming zone for a high migrant population coming from the northern region in search for farming land. The permanent movement between the hosting zone and the zone of origin for cultural reasons (traditional festivals, funerals, initiations rites, etc...) has served as a framework for the popularization of B. vulgaris and B. vulgaris var. striata 
whose plantings tend to spread over the whole country (Figure 2).

A very minute regional traffic of bamboos exists in West African countries notably in Burkina-Faso, Niger and Mali and concerns the sale of $O$. abyssinica culms. The local populations who exploit this bamboo and practice the trade live between Sotouboua and Bafilo cities, on the main road that crosses the country from the south to the north. In Dapaong region, Kanté and Niamtougou, the bamboo is used in the treatment of several diseases such as gonococci, malaria, yellow fever, jaundice, etc. The most spread species, then the most used in that part of Togo is $O$. abyssinica. It is used alone or generally mixed with other medicinal herbs. The parts used are the leaves, the roots, the culm or the bark of the culm. At the Sola's (Kara region), to hear dead people on the circumstances surrounding their death, the culms of $O$. abyssinica are tied with a white cloth to serve as spokesperson of the dead person: to a question asked, the movements of the culms are interpreted as a language that the initiates must decode and explain to the family of the deceased. The same species is used to make a flute which is played only during special ceremonies in Pagouda.

According to an outstanding experiment in Logodome Village (Prefecture of Vo), B. vulgaris is used in fertilizing the soil: the decomposition of the leaves buried in the soil in the dry season enriches the latter during farming.

In the craft, the common uses of the bamboo are as follows:

- Common uses in all the zones:

- Frame, ceiling, fence and roofing for houses;

- Hurdle for fences for houses;

- $\quad$ Poles for TV antennas;

- $\quad$ Hut and open shed;

- $\quad$ Cage for guinea fowl;

- Chairs and public benches;

- Basket

- $\quad$ Potsherds of flooring tile for houses;

- $\quad$ Firewood.

- Specific uses in certain zones:

- $\quad$ Bow for arrow (zone I and

II);

- Windbreak: reduces the force of the wind (zone V);

- $\quad$ Trap and bait for fish, crafts (zone IV and V);

- $\quad$ Making of pipe for running water (zone IV and V).

Table 1: Proportion of bamboo clumps visited in each ecological zone.

\begin{tabular}{lc}
\hline Zone & Percentage (\%) \\
\hline I & 2.6 \\
II & 26.5 \\
III & 10.8 \\
IV & 23.4 \\
V & 36.7 \\
\hline Total & 100 \\
\hline
\end{tabular}


Table 2: Bamboo species recently introduced by OIC-Togo.

\begin{tabular}{lc}
\hline Species & Origin \\
\hline Bambusa birmanica & Burma, India \\
Bambusa blumeana & South-East Asia \\
Bambusa beechyana & China \\
Bambusa edulis & Burma, China \\
Bambusa oldhamii & South of China \\
Bambusa dissimulator & China \\
Bambusa nutans & America \\
Bambusa polimorpha & Burma, Bengal \\
Bambusa ventricosa & China \\
Bambusa warmin & America \\
Dendrocalamus brandisii & India \\
Dendrocalamus latiflorus & South of China \\
Dendrocalamus membranaceus & Burma, Thaïland \\
Dendrocalamus strictus & Hawaii \\
Gigantochloa albociliata & Thaïland \\
Gigantocloa bali white & America \\
Gigantocloa luteostriata & America \\
Gigantocloa malay dwarf & Malaya \\
Guadua angustifolia & America \\
Guadua chacoensis & Southerica \\
\hline & \\
\hline
\end{tabular}

Table 3: Area occupies by the main sampled bamboo species in Togo.

\begin{tabular}{|c|c|c|c|c|}
\hline \multirow[t]{2}{*}{ Species } & \multicolumn{4}{|c|}{ Bamboo area (\%) } \\
\hline & $\begin{array}{l}\text { Small clumps } \\
<_{150 \mathrm{~m}^{2}}\end{array}$ & $\begin{array}{c}\text { Average clumps } \\
150-500 \mathrm{~m}^{2}\end{array}$ & $\begin{array}{l}\text { Big clumps } \\
500-2000 \mathrm{~m}^{2}\end{array}$ & Total \\
\hline Bambusa vulgaris & 30.2 & 22.2 & 30.5 & 82.9 \\
\hline Bambusa vulgaris striata & 1.3 & 3.8 & ----------- & 5.1 \\
\hline Oxytenanthera abyssinica & 2.5 & 7 & 2.5 & 12 \\
\hline Total (\%) & 34 & 33 & 33 & 100 \\
\hline
\end{tabular}


Table 4: Area occupied by the main bamboos species in each ecological zone.

\begin{tabular}{|c|c|c|c|c|c|}
\hline \multirow[t]{3}{*}{ Species } & \multirow[t]{3}{*}{ Zone } & \multicolumn{4}{|c|}{ Area occupied by the bamboos (\%) } \\
\hline & & Small clumps & Average clumps & Big clumps & \\
\hline & & $<150 \mathrm{~m}^{2}$ & $150-500 \mathrm{~m}^{2}$ & $500-2000 \mathrm{~m}^{2}$ & Total \\
\hline \multirow{4}{*}{ Bambusa vulgaris } & Zone II & 3.8 & 3 & 0.8 & 7.6 \\
\hline & Zone III & 2.5 & 4.1 & 4.2 & 10.8 \\
\hline & Zone V & 13.9 & 6.1 & 16.8 & 36.5 \\
\hline & Zone V & 10 & 9.4 & 8.7 & 28.1 \\
\hline \multirow{3}{*}{$\begin{array}{l}\text { Bambusa vulgaris } \\
\text { striata }\end{array}$} & Zone II & ------- & 0.5 & -------- & 0.5 \\
\hline & Zone V & 1.3 & 2.5 & -------- & 3.8 \\
\hline & Zone V & ------ & 0.5 & -------- & 0.5 \\
\hline \multirow{3}{*}{$\begin{array}{l}\text { Oxytenanthera } \\
\text { abyssinica }\end{array}$} & Zone I & $\begin{array}{l}------- \\
\end{array}$ & 1.9 & $\begin{array}{l}------- \\
\end{array}$ & 1.9 \\
\hline & Zone II & 0.6 & 5 & 2.5 & 8.1 \\
\hline & Zone V & 1.9 & -------- & -------- & 1.9 \\
\hline Total $(\%)$ & & 34 & 33 & 33 & 100 \\
\hline
\end{tabular}

Table 5: Leaves characteristics of the main bamboos collected in Togo.

\begin{tabular}{llclllll}
\hline \multirow{2}{*}{ Species } & \multirow{2}{*}{ Sheath (cm) } & Limb (cm) & \multicolumn{2}{c}{ Ligula (cm) } \\
\cline { 3 - 8 } & Zone & Length & Width & Length & Width & Length & Width \\
\hline Bambusa vulgaris & Zone II & $6.7 \pm 1.6$ & $0.6 \pm 0.2$ & $19.5 \pm 3.7$ & $3.0 \pm 0.6$ & NA $^{1}$ & NA \\
& Zone III & $7.4 \pm 1.3$ & $0.6 \pm 0.2$ & $24.1 \pm 4.0$ & $2.9 \pm 1.2$ & NA & NA \\
& Zone V & $9.3 \pm 1.4$ & $0.6 \pm 0.2$ & $25.6 \pm 3.7$ & $3.1 \pm 1.1$ & NA & NA \\
& Zone V & $7.3 \pm 1.5$ & $0.9 \pm 0.2$ & $28.5 \pm 2.8$ & $3.9 \pm 0.8$ & NA & NA \\
\hline Bambusa vulgaris & Zone IV & $9.2 \pm 0.0$ & $1.0 \pm 0.3$ & $28.8 \pm 3.9$ & $4.1 \pm 1.3$ & NA & NA \\
striata & Zone V & $8.0 \pm 0.0$ & $0.7 \pm 0$ & $22.2 \pm 0.0$ & $4.1 \pm 0.0$ & NA & NA \\
\hline Oxytenanthera & Zone I & $7.3 \pm 3.1$ & $1.0 \pm 0.4$ & $14.0 \pm 4.2$ & $2.8 \pm 1.3$ & $0.6 \pm 0.1$ & $0.5 \pm 0.1$ \\
abyssinica & Zone II & $7.1 \pm 1.1$ & $0.8 \pm 0.3$ & $19.7 \pm 3.6$ & $2.9 \pm 0.8$ & $0.6 \pm 0.4$ & $0.6 \pm 0.4$ \\
\hline
\end{tabular}

${ }^{1} \mathrm{NA}=$ non available data. 
Table 6: Dendrometric characteristics of the main bamboos in Togo.

\begin{tabular}{lccccc}
\hline Species & Zone & $\begin{array}{c}\text { Average } \\
\text { dominant } \\
\text { height } \\
(\mathbf{m})\end{array}$ & $\begin{array}{c}\text { Average } \\
\text { length of } \\
\text { internodes } \\
(\mathbf{c m})\end{array}$ & $\begin{array}{c}\text { Circumference } \\
(\mathbf{c m})\end{array}$ & $\begin{array}{c}\text { Thickness } \\
(\mathbf{c m})\end{array}$ \\
\hline \multirow{2}{*}{ Bambusa } & Zone II & $23.27 \pm 7.03$ & $30.16 \pm 1.60$ & $24.60 \pm 2.49$ & $2.16 \pm 0.35$ \\
vulgaris & Zone III & $24.25 \pm 9.82$ & $29.06 \pm 2.07$ & $18.39 \pm 2.60$ & $1.89 \pm 0.39$ \\
& Zone IV & $27.68 \pm 7.46$ & $31.85 \pm 2.62$ & $25.07 \pm 2.18$ & $1.8 \pm 0.27$ \\
& Zone V & $17.14 \pm 6.33$ & $27.74 \pm 2.19$ & $16.23 \pm 2.71$ & $1.67 \pm 0.39$ \\
\hline \multirow{3}{*}{ Bambusa } & Zone II & $10.00 \pm 0.00$ & $24.00 \pm 0.71$ & $19.15 \pm 2.66$ & $1.70 \pm 0.00$ \\
vulgaris striata & Zone IV & $20.60 \pm 5.49$ & $25.30 \pm 1.45$ & $29.20 \pm 1.93$ & $2.26 \pm 0.29$ \\
Oxytenanthera V & $25.00 \pm 0.00$ & $25.16 \pm 1.65$ & $20.91 \pm 1.71$ & $1.75 \pm 0.00$ \\
abysinica & Zone I & $08.50 \pm 1.79$ & $28.70 \pm 1.49$ & $13.08 \pm 1.88$ & $4.17 \pm 0.60$ \\
\hline
\end{tabular}

Table 7: Origin of the bamboo nurseries at the time of planting.

\begin{tabular}{lc}
\hline Origin & Percentage (\%) \\
\hline Zone IV & 20.4 \\
Benin & 1.2 \\
Ghana & 0.6 \\
Local (collected on the spot at the time of planting) & 77.8 \\
Total & 100 \\
\hline
\end{tabular}

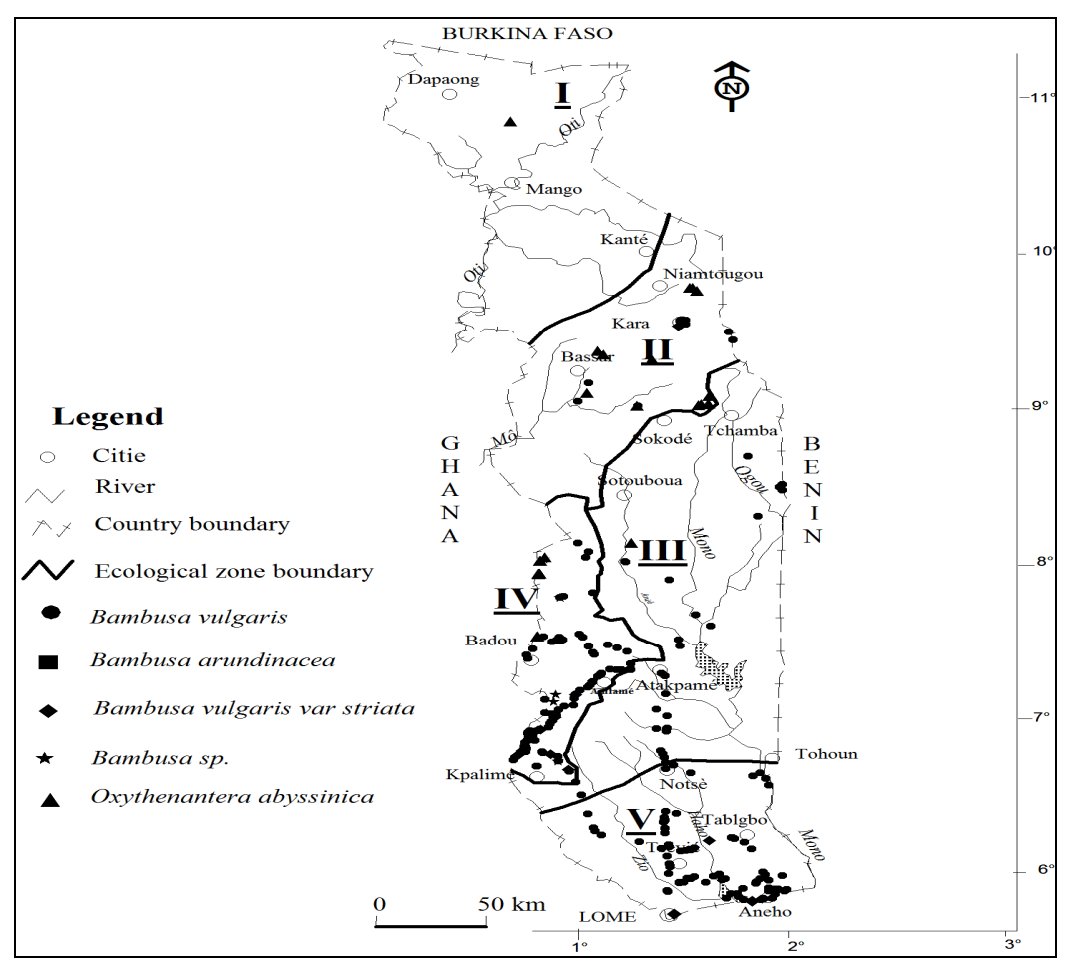

Figure 2: Bamboo species distribution in Togo. 


\section{DISCUSSION}

This study is the first survey of the bamboo resources in Togo that helped to locate 257 sites spread all over the country. This inventory is far from being exhaustive, because many localities remain to be prospected, especially in the Litimé plain (Zone IV) where bamboo clumps are abundant. Moreover, in terms of specific diversity, some authors add to the recorded species Olyra latifolia, a small forest Graminae present in Togo (INBAR-Togo, 2002).

The current results show that most of the bamboo clumps in Togo come from natural groves $(76.6 \%)$. The very important presence of the natural groves protected by the population shows, on the one hand, the value given to bamboo in daily uses. On the other hand, the proportion of the private plantations (23.4\%) is very significant because it shows the knowledge of the population about the usual values of bamboo. This fringe of population which plants bamboo constitutes the target that should be associated to a possible production programme.

$B$. vulgaris is the dominant species in Togo $(85.21 \%)$. It is present all over the country except in zone I where it is $O$. abyssinica which takes largely the upper hand. Currently, anatomical analysis and other properties permitted to notify that at least two species were grouped together as Bambusa vulgaris. A bamboo species very close to Bambusa vulgaris, actually named Bambusa sp. (taxonomy must be clarified), represented around $2.33 \%$ of the bamboos clumps listed in Togo and its area is confined to ecological zone IV. Sometimes it was found on the same sites as Bambusa vulgaris, in depressions along rivers (Kokutse et al., 2013; Figure 2).

Today, B. vulgaris asserts in Togo as the species on which farming programmes can rely on, in view of the good morphological performances of this bamboo. Abd-Latif and Liese (2002) testifies that the use of bamboos is directly linked to this morphological performance of culms. This species could have been privileged by O.I.C.-Togo which imported bamboos from Hawaiian Islands and is currently keen to promote their farming in Togo (Siativi, 2004). It is due to lack of accurate information such as that provided in this article that this NGO based the essential of its activities on bamboos recently introduced even though it could have relied on the existing one. The populations exhibit some manners which favour the spread of the bamboos in Togo because $23.4 \%$ of bamboo clumps are private plantations. It appears that the zone IV is the supplying zone of plantations for $20.7 \%$ of sampled sites. The permanent movement between this hosting zone of farmers and their village of origin favours this popularization of bamboos notably B. vulgaris, B. vulgaris var. striata. A sensitization of the rural populations would be sufficient to amplify this action.

The Bamboo is mostly considered as an invasive species in certain localities. In other zones, notably zone II, the use of natural bamboo clumps and private ones as windbreak is already part and parcel of people's habit. The setting up of bamboo farm constitutes an advantage for the use of the forestry resource still not well known, but which requires an integrated development policy, and which takes into consideration the realities and the needs of the area notably a regeneration plan of the farming lands. As part of the extension policy of the bamboo farms, the scarcity of farming lands supposes a reticence of the population to let a portion of the reserved areas to livelihood farming. The sociodemographic characteristics are also decisive in the choice of the sites to be retained for a extension programme and national production of bamboo. In the farming zones, the development and the introduction of fertilization 
technique of soil with bamboo leaves would be an advantage for the adherence of the population to a possible extension programme of the bamboos.

The development of bamboo farming in Togo appears to be an alternative to reduce the pressure on forest species. But the socioeconomic study reveals that the use of bamboo in Togo still remains traditional (Kokou et al., 2006). It is more used in buildings construction and in crafts, in contrary to Ghana where the bamboo already replaces validly the timbers in carpentry. In this country, industries and companies are highly specialized in the transformation of bamboo. This stage is necessary and indispensable to back a sustained production and a sustainable exploitation of bamboos resources in Togo.

\section{Conclusion}

This study has helped to locate the bamboo species present in Togo. Only $O$. abyssinica is originated from sudanian zone of Togo. Other species have been introduced for a very long-time (B. vulgaris,) or recently ( $B$. vulgaris var. striata, B. multiplex). Other twenty species are being acclimatized at O.I.C.-Togo. B. vulgaris represents alone $85.21 \%$ of bamboo clumps in Togo. The morphological characteristics of each species vary according to the ecological zones and human pressure on the clumps. These characteristics are described to enable the choice of adequate material as part of an extension of bamboo farms in Togo. $O$. abyssinica is well adapted in the northern part of Togo in sudanian zone while B. vulgaris and $B$. vulgaris var. striata are to be promoted for industrial uses in guinean zone of Togo.

The assessment of the usual practices linked to the bamboo shows that in the whole Togo, production, exploitation and processing are still at the traditional stage. Taking into consideration the different socio-economic practices in which the bamboo intervenes, activities of O.I.C.-Togo are to be acknowledged but must integrate a national programme of production as alternative for a better management of forestry resources. The production requires also exploitation and processing of products like the case of certain countries of the sub-region (Ghana in particular) where the processing technique of bamboo is now at the industrial level.

Now that the management of the environment implies a better exploitation of the available natural resources, bamboo can validly assert as a source of supply in firewood, service and construction to limit human pressure on traditional plant species whose reduction causes an imbalance of the biodiversity.

\section{ACKNOWLEDGEMENTS}

The current study has been sponsored by African Academy for Sciences (AAS) and the African Forest Research Network (AFORNET).

\section{REFERENCES}

Abd-Latif M, Liese W. 2002. Culm characteristics of two bamboos in relation to age height and site. In Bamboos for Sustainable Development, Kumar AI, Rao R, Sastry C (eds). Kuala Lumpur: Malaysia; 223-233.

Abdul Khalil HPS, Bhat IUH, Jawaid M, Zaidon A, Hermawan D, Hadi YS. 2012. Bamboo fibre reinforced biocomposites: A review. Materials and Design, 42: 353-368.

Akpagana K. 1989. Recherches sur les forêts denses humides du Togo. Thèse de Doctorat, Univ. Bordeaux 3, France, p.181.

Aubréville A. 1937. Les forêts du Dahomey et du Togo. Bulletin du Comité d'Etudes Historiques, 29: 1-11.

Banik RL. 1993. Morphological characters for culm age determination of different bamboo 
species Bangladesh. Bang. Jour. For. Sci., 22(2):18-22.

Banik RL. 1997. Domestication and improvement of bamboos, INBAR's working paper No. 10, New Delhi, India.

Brunel JF, Hiepko P, Scholz H. 1984. Flore Analytique $d u$ Togo. Phanérogames: Eschborn, Germany.

Chen X. 2003. Promotion of Bamboo for Poverty Alleviation and Economic Development. In Proceeding of International Workshop on Bamboo industrial utilization. INBAR. New Delhi

Embaye K, Christersson L, Ledin S, Weih M. 2003. Bamboo as bioresource in Ethiopia: management strategy to improve seedling performance (Oxytenanthera abyssinica). Bioresource Technology, 88: 33-39.

Ern H. 1979. Die vegetation Togos. Gliederrung. Erhaltung. Willdenowia, 9: 295-312.

Food and Agriculture Organization of the United Nations. 2005. World Bamboo Resources - a thematic study prepared in the framework of the Global Forest Resources Assessment 2005, FAO .

Food and Agriculture Organization of the United Nations. 2001. Global Forest Resources Assessment 2000. Main Report. FAO, Rome, p.479.

Guelly KA. 1994. Les savanes de la zone forestière subhumide du Togo. Thèse de Doctorat, Université Pierre et Marie Curie, Paris IV, p.163.

INBAR-Togo. 2002. Recensement et valorisation des bambous et rotins du Togo. Rapport de projet INBAR, p.10.

Kokou K, Kokutse AD, Aményédzi A, Adjonou K, Kpodar F, Guelly AK. 2006. Diagnostic socio-éco économique sur la valorisation du bambou au Togo. Rev. Sc. Env. Univ. Lomé., 2: 3-27.

Kokou K. 1998. Les Mosaïques forestières au Sud du Togo: biodiversité, dynamique et activités humaines, Thèse de Doctorat Univ Montpellier 2, France, p139.

Kokutse AD, Wiyaou G, Kokou K. 2013. Anatomical, physical and mechanical properties variability of Togo bamboos. Rev. CAMES., 1: 28-38

Liese W. 1998. The anatomy of bamboo culms. INBAR Technical. Report No.18, New Delhi p.204.

Lobovikov M, Paudel S, Piazza M, Ren H, Wu J. 2007. World Bamboo Resources: a thematic study prepared in the framework of the Global Forest Resources Assessment 2005, FAO, Rome.

Muller I, Rebelo C. 2010. Bamboo Worldwide: the current Market and Future potential. EcoPlanet Bamboo Report, p.30.

Rassiah K, Megat Ahmad MMH, Ali A. 2014. Mechanical properties of laminated bamboo strips from Gigantochola Scortechiniil polyester composites. Materials and Design, 57: 551-559.

Siativi AF. 2004. Contribution au développement de la culture du bambou au Togo : cas de l'OICTOGO. Mémoire de l'INFA de Tové, p.39.

Scurlock JMO, Dayton DC, Hames B. 2000. Bamboo : an overlooked biomass resource? Biomass and Bioenergy, 19: 229-244.

Song X, Zhou G, Jiang H, Yu S, Fu J, Li W, Wang W, Ma Z, Peng C. 2011. Carbon sequestration by Chinese bamboo forests and their ecological benefits: assessment of potential, problems, and future challenges. Environ. Rev., 19: 418428.

Trochain JL. 1957. Accord interafricain sur la définition des types de végétation de l'Afrique Tropicale. Bulletin International d'Etudes Centrafricaines, Nouvelle série, Brazzaville, 13(14): 56-93. 